\title{
Interferon- $\alpha$ induces apoptosis in human KB cells through a stress-dependent mitogen activated protein kinase pathway that is antagonized by epidermal growth factor
}

M. Caraglia ${ }^{1}$, A. Abbruzzese ${ }^{\star, 1}$, A. Leardi ${ }^{2}$, S. Pepe ${ }^{2}$, A. Budillon ${ }^{3}$, G. Baldassare ${ }^{3}$, C. Selleri ${ }^{2}$, S. De Lorenzo ${ }^{2}$, A. Fabbrocini' ${ }^{2}$, G. Giuberti ${ }^{1}$, G. Vitale ${ }^{2}$, G. Lupoli ${ }^{2}$, A.R. Bianco ${ }^{2}$ and P. Tagliaferri ${ }^{2,4}$

1 Dipartimento di Biochimica e Biofisica 'F. Cedrangolo', II Università di Napoli, Italy

2 Dipartimento di Endocrinologia ed Oncologia Molecolare e Clinica, Università 'Federico II' di Napoli, Italy

3 Istituto Nazionale Tumori, Fondazione 'G. Pascale', Napoli, Italy

${ }^{4}$ Current address: Dipartimento di Medicina Sperimentale e Clinica, Università 'Magna Graecia', Catanzaro, Italy

* corresponding author: Alberto Abbruzzese, Dipartimento di Biochimica e Biofisica 'F. Cedrangolo', II Università di Napoli, via Costantinopoli, 1680138 Napoli, Italy tel: +39 81 5665871; fax: +39 81 5665863;

e-mail: abbruzze@cds.unina.it

Received 21.10.98; revised 15.4.99; accepted 9.6.99 Edited by S. Martin

\begin{abstract}
We have demonstrated that interferon- $\alpha 2$-recombinant (IFN $\alpha$ ) at growth inhibitory concentrations enhances the expression and signalling activity of the epidermal growth factor receptor (EGF-R) in human epidermoid carcinoma KB cells. Here we report that $K B$ cells exposed to IFN $\alpha$ underwent apoptotic cell death and this effect was antagonized by EGF. We have also found that IFN $\alpha$ enhanced the expression of heat shock proteins (HSP) HSP-70, HSP-90 and HSP-27 and activated the $\mathrm{NH}_{2}$-terminal Jun kinase-1 (JNK-1) and p38 mitogen activated protein kinase, the target enzymes of a stress-dependent intracellular transduction pathway. Moreover, the overexpression of the wild-type JNK-1, obtained through plasmid transfection of KB cells, induced apoptosis which was potentiated by the exposure of wild-type JNK-1 (JNK-1 ${ }^{\text {wt }}$ )transfected cells to IFN $\alpha$. All these effects were neutralized by the addition of EGF to parental and JNK-1 ${ }^{\text {wt }}$-transfected KB cells exposed to IFN $\alpha$. In conclusion, EGF has a protective effect on KB cells from apoptosis while antagonizing a stress response elicited by IFN $\alpha$ and targeted on the stress pathway terminal kinases.
\end{abstract}

Keywords: Interferon- $\alpha$; epidermal growth factor; tumour cells; apoptosis; JNK-1; heat shock proteins

Abbreviations: ATP, adenosine 5'-triphosphate; BSA, bovine serum albumin; DMEM, Dulbecco's modified Eagle's medium; DTT, dithiothreitol; EDTA, ethylenediaminetetracetic acid; EGF, epidermal growth factor; EGF-R, EGF receptor; EGTA, Ethylene- glycol-bis( $\beta$-aminoethyl Ether) $\mathrm{N}, \mathrm{N}, \mathrm{N}^{\prime}, \mathrm{N}^{\prime}$-tetraacetic acid; ERK, extracellular signal regulated kinase; FBS, foetal bovine serum; HEPES, N-2-hydroxyethylpiperazine- $\mathrm{N}-2$ '-ethanesulphonic acid; HSP, heat shock protein; IFN- $\alpha$, recombinant interferon- $\alpha$; JNK, $\mathrm{NH}_{2}$ terminal Jun kinase; JNK-1 ${ }^{\text {wt }}$, wild-type JNK-1; MAb, monoclonal antibody; MAPK, mitogen activated protein kinase; MAPK ${ }^{\mathrm{p} 38}$, p38 MAPK; PAGE, polyacrylamide gel electrophoresis; PBS, phosphate buffered saline; $P C N A$, proliferating cell nuclear antigen; PGF, peptide growth factor; PI, propidium iodide; PMSF, phenylmethylsulphonyl fluoride; SAPK, stress-activated protein kinase; SDS, sodium-dodecyl-sulphate; TGF $\beta$, transforming growth factor $\beta$; TRF-R, transferrin receptor; Tris, Tris(hydroxymethyl) methylamine

\section{Introduction}

The molecular interaction between growth promoting and growth inhibiting cytokines in the tumour microenvironment is an important issue in the study of tumour cell growth regulation. ${ }^{1}$ The potential selectivity of cytokine network underlines its possible role as specific target for new molecularly designed anticancer approaches.

We have reported that recombinant interferon- $\alpha$ (IFN $\alpha)$ at cytostatic concentrations upregulates the expression of epidermal growth factor (EGF-R) and transferrin (TRF-R) receptors. ${ }^{2-4}$ We have also demonstrated that the proliferative response of human epidermoid cancer KB cells to EGF is increased by IFN $\alpha .{ }^{5}$ This latter effect is paralleled by an increased tyrosine phosphorylation of cellular proteins and of the EGF-R itself in KB cells exposed to IFN $\alpha{ }^{5}$ it is suggested that the EGF-R signalling is upregulated in IFN $\alpha-$ treated tumour cells. ${ }^{5}$ We have speculated that the enhanced expression and function of EGF-R by the tumour cells could represent a stress response that might be activated as an attempt to provide an escape mechanism to the growth inhibition induced by IFN $\alpha .{ }^{6}$ Moreover, it is reported that IFN $\alpha$ induces apoptosis on human squamous cancer, ${ }^{7}$ glioma $^{8}$ and virus-infected cells. ${ }^{9}$ On the other hand, epidermal growth factor (EGF) is able to protect eukaryotic cells from the onset of programmed cell death. ${ }^{10-12}$ Evidence exists about the involvement of stress response in the mechanisms of protection from apoptosis in eukaryotic cells. ${ }^{13,14}$ In fact, the apoptosis induced by nitric oxyde, a classical shock agent, is prevented by the increased expression of heat shock protein (HSP)-70 in vascular smooth muscle cells. ${ }^{15}$ Moreover, it has been reported that a hypoxic stress induces EGF-R upregulation and increases HSP expression in human tumour cells ${ }^{16}$ and HSPs themselves confer protection against apoptosis induced by several injuries in cardiocytes and cancer cells. ${ }^{13,14}$ Therefore, EGF-R upregulation and stress protein induction could be convergent in the 
protection from programmed cell death. It has been described that cytokines that do not contain a 'death domain', such as transforming growth factor $\beta$ (TGF $\beta$ ), can elicit apoptosis and stress response through the induction of a shock-dependent mitogen activated protein kinase (MAPK) cascade that involves $\mathrm{NH}_{2}$ terminal Jun kinase (JNK) and stress-activated protein kinase (SAPK) family. ${ }^{17-19}$ Moreover, it has been reported that peptide growth factor (PGF)- induced extracellular signal regulated kinase (ERK) mediates a strong anti-apoptotic effect. ${ }^{20,21}$ In fact, ERK plays an important role in protecting cardiac myocytes from apoptotic death following oxidative stress. ${ }^{22}$ Protection of PC12 cell death by $\mathrm{N}$-acetylcysteine requires $\mathrm{ERK}$ activation ${ }^{21}$ that is, moreover, involved in the phorbol myristate acetate-mediated inhibition of drug-induced apoptosis in tumour cells. ${ }^{23}$ On the basis of these considerations, we have investigated if
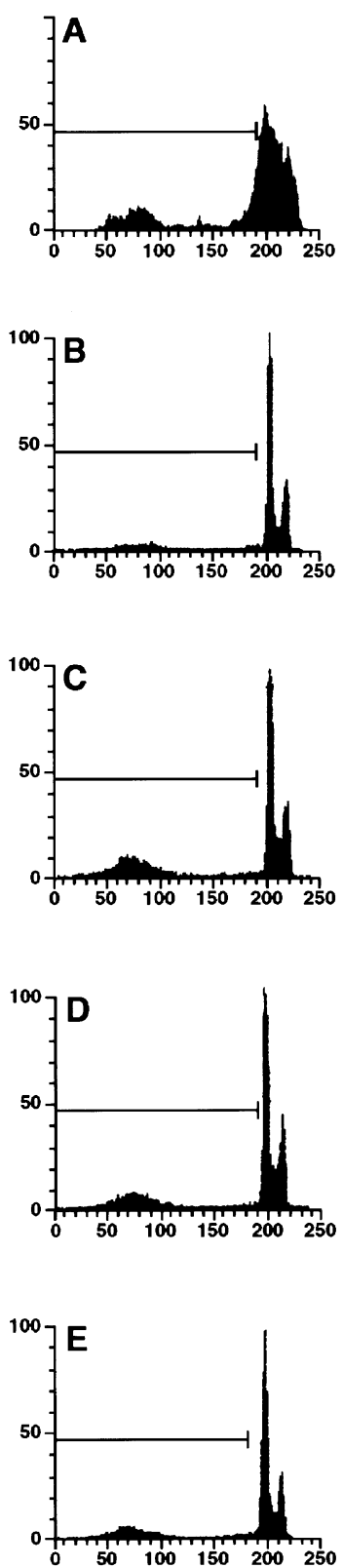

$\mathbf{F}$
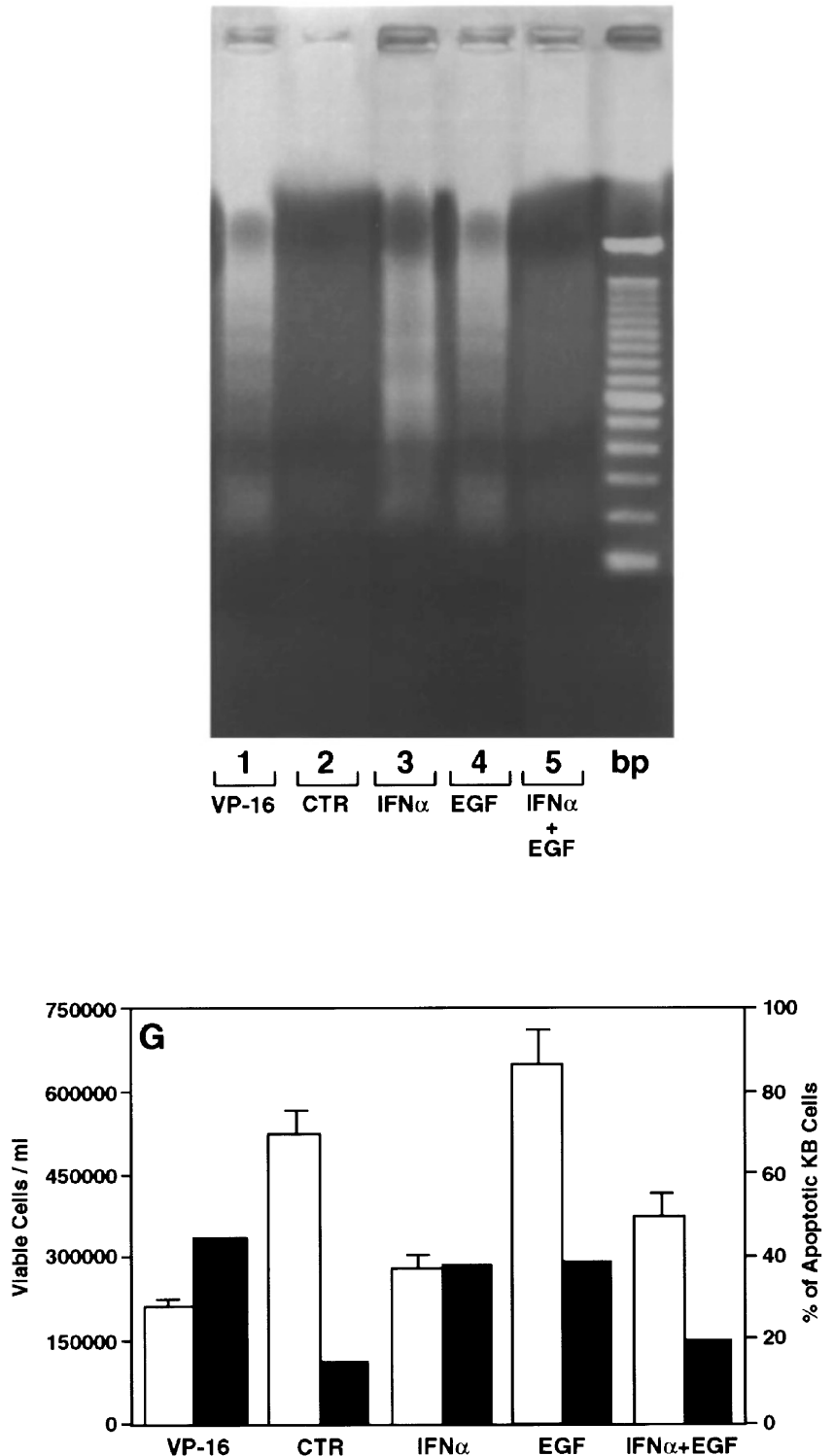

Figure 1 Effects of INF $\alpha$ and EGF on apoptotic events in KB cells. (A-E) FACS analysis of KB cells exposed to $1000 \mathrm{IU} / \mathrm{ml} \mathrm{IFN} \alpha$ for $48 \mathrm{~h}$ and/or $12 \mathrm{~h} 10 \mathrm{nM}$ EGF. $\mathrm{KB}$ cells have been collected, labelled with propidium iodine and analyzed as described in 'Materials and Methods'. (A) positive controls (48 $50 \mu \mathrm{M}$ VP-16); (B) untreated; (C) $48 \mathrm{~h} 1000 \mathrm{IU} / \mathrm{ml} \mathrm{IFN} \alpha$; (D) $12 \mathrm{~h} 10 \mathrm{nM} \mathrm{EGF;} \mathrm{(E)} 48 \mathrm{~h} 1000 \mathrm{IU} / \mathrm{ml} \mathrm{IFN} \alpha+12 \mathrm{~h} 10 \mathrm{nM}$ EGF. The experiments were performed at least three times and always gave similar results. (F) Internucleosomic DNA fragmentation of KB cells exposed to $1000 \mathrm{IU} / \mathrm{ml} \mathrm{IFN} \alpha$ and/or $10 \mathrm{nM}$ EGF evaluated with gel ladder analysis as described in 'Materials and Methods'. Lane 1, positive controls (48h $50 \mu \mathrm{M} \mathrm{VP-16);} \mathrm{lane} \mathrm{2,} \mathrm{untreated} \mathrm{controls;} \mathrm{lane} \mathrm{3,} 48 \mathrm{~h} 1000 \mathrm{IU} / \mathrm{ml}$ IFN $\alpha$; lane 4, $12 \mathrm{~h} 10 \mathrm{nM}$ EGF; lane 5, $48 \mathrm{~h} 1000 \mathrm{IU} / \mathrm{ml} \mathrm{IFN} \alpha+12 \mathrm{~h} 10 \mathrm{nM}$ EGF. (G) Apoptosis (ם) was expressed as percentage of cell population and number of viable cells ( $\square$ ) was determined by haemocytometric cell count after trypan blue dye. VP-16, positive controls (48 h $50 \mu \mathrm{M}$ VP-16); CTR, untreated; IFN $\alpha, 48 \mathrm{~h} 1000 \mathrm{IU} / \mathrm{ml}$ IFN $\alpha$; EGF, $12 \mathrm{~h} 10 \mathrm{nM}$ EGF; IFN $\alpha+E G F, 48 \mathrm{~h} 1000 \mathrm{IU} / \mathrm{ml}$ IFN $\alpha+12 \mathrm{~h} 10 \mathrm{nM}$ EGF. For cell proliferation experiments each point represents the mean of at least three different experiments. Bars, S.D. 
apoptotic events were induced by IFN $\alpha$ on KB cells and if they could be prevented by the exposure to EGF. We have indeed found that EGF-R overexpression was paralleled by apoptotic cell death in IFN $\alpha$-treated KB cells. Therefore, we have investigated whether IFN $\alpha$-induced upregulation of EGF-R could be explained as an anti-apoptotic protective stress response of KB cells. Therefore, we have evaluated if IFN $\alpha$ modified the expression of HSPs and if EGF antagonized this effect. Finally, we have studied the involvement of JNK-1 and p38 MAPK (MAPK ${ }^{\mathrm{p} 38}$ ), the terminal enzymes of a stress-activated pathway ${ }^{24}$ implicated in cell death, ${ }^{17,20,25,26}$ in the interaction of IFN $\alpha$ and EGF on the triggering of apoptosis.

\section{Results}

\section{Apoptosis was induced by IFN $\alpha$ and antagonized by EGF in KB cells}

Apoptotic cell death is induced by IFN $\alpha$ in virus-infected and tumour cells. ${ }^{7-9}$ However, the molecular underlying mechanisms of this effect are not well defined. We have previously reported that the treatment with $1000 \mathrm{IU} / \mathrm{ml} \mathrm{IFN} \alpha$ for $48 \mathrm{~h}$ induces $50 \%$ growth inhibition and EGF-R upregulation on $\mathrm{KB}$ cells. ${ }^{5}$ We have found that, at these experimental conditions, $40 \%$ of IFN $\alpha$-treated KB cells were apoptotic as demonstrated by internucleosomic DNA fragmentation and quantitized by FACS analysis after nuclear dye with propidium iodide (Figure $1 \mathrm{C}, \mathrm{F}$ and $\mathrm{G}$ ). Apoptosis induction was further demonstrated by TUNEL technique (Figure $2 \mathrm{~B}$ ). Programmed cell death was markedly reduced when $10 \mathrm{nM}$ EGF was added for $12 \mathrm{~h}$ to IFN $\alpha$-treated KB cells (Figures 1E, F and G, and 2D). In fact, in these experimental conditions only about $20 \%$ of KB cells were apoptotic versus $18 \%$ of control cells (Figure $1 \mathrm{G}$ ). Also the exposure of $\mathrm{KB}$ cells for $12 \mathrm{~h}$ to $\mathrm{EGF}$ alone induced apoptotic death in about $37 \%$ of KB cells (Figures 1D and G,

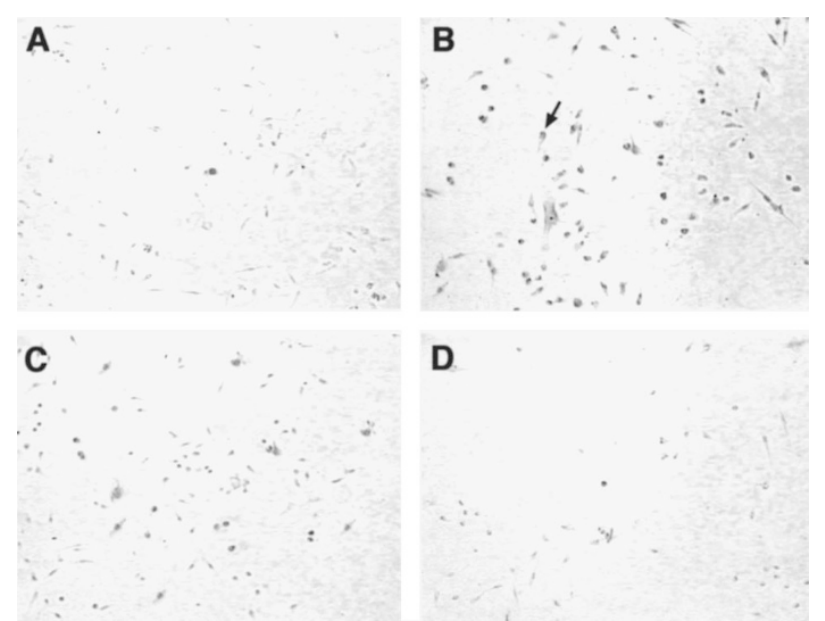

Figure 2 TUNEL of KB cells exposed to IFN $\alpha$ and/or EGF. Apoptosis was detected by TUNEL technique as described in 'Materials and Methods'. Arrow shows an example of apoptotic nucleus. Untreated controls (A), 48 h $1000 \mathrm{IU} /$ $\mathrm{ml} \mathrm{IFN} \alpha$-treated (B), $12 \mathrm{~h} 10 \mathrm{nM}$ EGF-treated (C) and $48 \mathrm{~h} 1000 \mathrm{IU} / \mathrm{ml} \mathrm{IFN} \alpha$ $+12 \mathrm{~h} 10 \mathrm{nM}$ EGF-treated KB cells (D). At least 500 cells from each sample were counted. Each quantification was done in triplicate and $2 \mathrm{C}$ ). The latter effect was however paralleled by enhanced proliferation as demonstrated by the increased number of viable cells as evaluated by haemocytometric cell count after trypan blue dye and by the increased PCNA expression as evaluated with FACS analysis (Figure 1G and data not shown, respectively). On the other hand, viable cells were about $50 \%$ reduced in IFN $\alpha$-treated cells and the EGF antagonism on the apoptosis induced by the cytokine was paralleled by only a partial rescue of the viable cell number (Figure 1G). The data derived from FACS analysis were confirmed by determination of apoptotic cells by TUNEL technique (see Figure 2). In fact, IFN $\alpha$ induced an increase of red nuclei number that was almost completely abrogated when IFN $\alpha$-treated cells were exposed for $12 \mathrm{~h}$ to EGF (Figure 2B and D, respectively). EGF alone caused again apoptosis in KB cells (Figure 2C). Therefore, IFN $\alpha$-induced

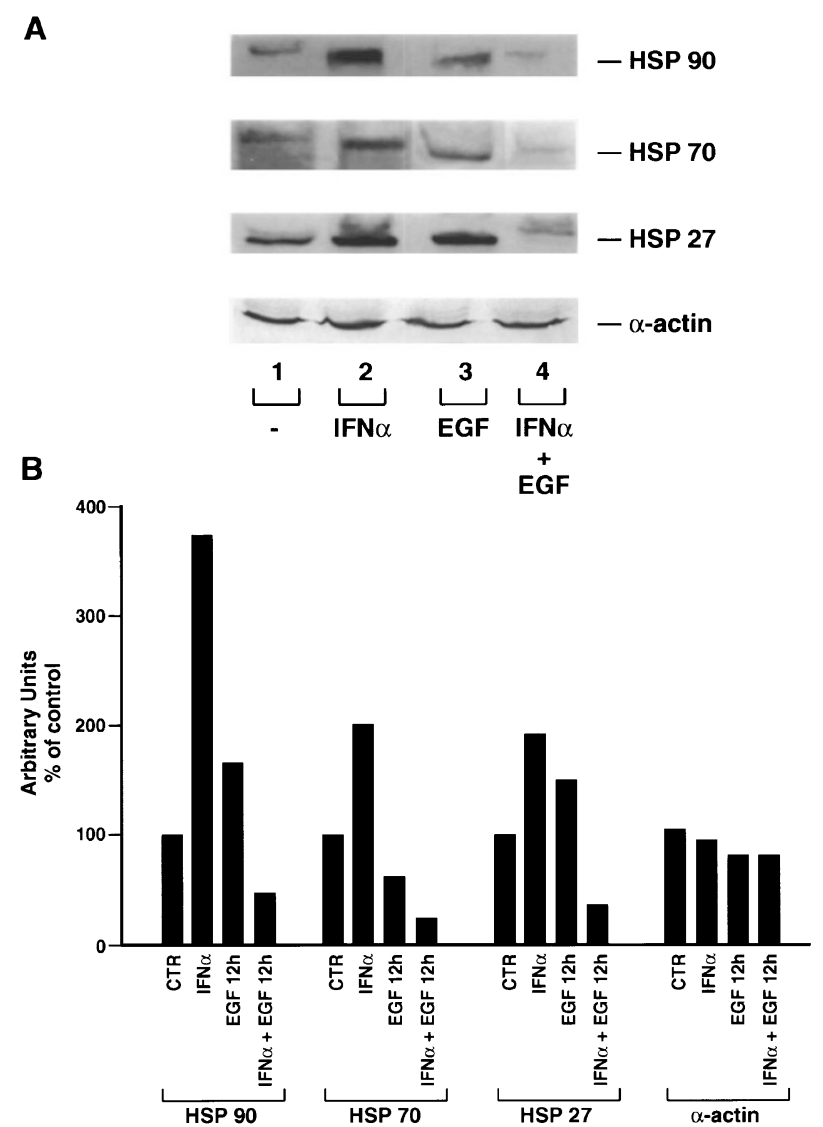

Figure 3 The effects of IFN $\alpha$ and EGF on cell contents of HSP-90, HSP-70 and HSP-27 in KB cells. (A) $150 \mu \mathrm{g}$ of cell proteins/lane have been assessed by Western blot analysis after electrotransfer to nitrocellulose filter of whole cell lysates which have been separated by PAGE and hybridized with anti-HSP-70 C92F3A-5 or anti-HSP-90 AC88 or anti-HSP-27 G3.1 or anti- $\alpha$-actin MAbs. Specific MAb binding has been detected by colorimetric reaction following alkaline phosphatase-linked anti-mouse antibody blotting. Cells have been cultured for $48 \mathrm{~h}$ in the absence of $1000 \mathrm{IU} / \mathrm{ml}$ of IFN $\alpha$ and exposed for different times to $10 \mathrm{nM}$ EGF. Cell treatment has been performed as follows: Lane 1, untreated controls; lane 2, $48 \mathrm{~h} 1000 \mathrm{IU} / \mathrm{ml} \mathrm{IFN} \alpha$; lane 3, 12 h 10 nM EGF; lane 4, $48 \mathrm{~h} 1000 \mathrm{IU} / \mathrm{ml} \mathrm{IFN} \alpha+12 \mathrm{~h} 10 \mathrm{nM}$ EGF. The experiments were performed at least three times and always gave similar results. (B) Laser scanning of the bands corresponding to HSPs in the Western blot experiment expressed as Relative Arbitrary Units (percentage of control) derived from a common software (Gel-Pro Analyzer, Media Cybernetics, Silver Spring, MD, USA) 
growth inhibition was likely due to the onset of apoptotic events in human KB cells.

\section{Antagonism between IFN $\alpha$ and EGF on HSP expression}

We have speculated that the enhanced expression and function of EGF-R by the tumour cells could represent a stress response as an attempt to overcome the apoptosis induced by IFN $\alpha .{ }^{6}$ Therefore, we have studied if the expression of HSPs was modulated by IFN $\alpha$ and if EGF could neutralize the changes of HSP expression. KB cells exposed for $48 \mathrm{~h}$ to IFN $\alpha$ showed an about fourfold increase of HSP-90 and an about twofold enhance of inducible HSP-70 and HSP-27 expression, as evaluated by Western blot analysis (Figure 3A, lane 2 and Figure 3B). The exposure of IFN $\alpha$-treated KB cells to $10 \mathrm{nM}$ EGF markedly reduced the expression of these proteins also if compared with that of untreated $K B$ cells (Figure $3 \mathrm{~A}$, lane 4 and Figure $3 \mathrm{~B}$ ). On the other hand, the addition of $10 \mathrm{nM}$ EGF for $12 \mathrm{~h}$ induced an about $50 \%$ increase of HSP-90 and HSP-27 expression (Figure 3A, lane 3 and Figure 3B). The expression of a housekeeping protein, $\alpha$ actin, was unaffected by the treatment with IFN $\alpha$ and/or EGF (Figure $3 A$ and $B$ ). In these experiments EGF was added to KB cells exposed to IFN $\alpha$ which was not withheld by the medium. We conclude that the abrogation of apoptosis induced by IFN $\alpha$ was paralleled by a reduction of HSP expression in KB cells.

\section{EGF antagonized the activation of JNK-1 and p38 MAPK (MAPK ${ }^{\text {p38}}$ ) in IFN $\alpha$-treated KB cells}

We have evaluated the effects of IFN $\alpha$ and EGF on the stressinduced pathway of MAPK isoenzymatic activity JNK-1 and
$\mathrm{MAPK}^{\mathrm{p} 38}$ in KB cells. We have found that the chronic exposure (48 h) to IFN $\alpha$ induced an about fivefold increase of activity of these proteins as evaluated with an enzymatic assay after immunoconjugation (Figure 4A and $B$ ). The exposure to EGF of IFN $\alpha$-treated KB cells caused a progressive reduction of the activity of the two enzymes which reached almost basal levels after $6 \mathrm{~h}$ of exposure to EGF (Figure 4A and B). However, EGF did not induce any change of the activity of JNK-1 and MAPK ${ }^{\mathrm{p} 38}$ in KB cells not exposed to IFN $\alpha$. At the same time, also the phosphorylated isoforms of $\mathrm{JNK}-1$ and $\mathrm{MAPK}^{\mathrm{p} 38}$ (Figure $4 \mathrm{~A}$ and $\mathrm{B}$, arrows in lower panel) were increased in IFN $\alpha$-treated cells while exposure to EGF progressively reduced their phosphorylation as demonstrated with a gel retardation assay (Figure 4A and B). Therefore, the effects of EGF and IFN $\alpha$ on apoptosis and HSP expression were paralleled by changes of the activity of the stress-inducible JNK-1 and MAPK ${ }^{\mathrm{p} 38}$.

\section{The transfection of the wild-type JNK-1 (JNK-1 ${ }^{\text {wt }}$ ) enhanced the apoptosis induced by IFN $\alpha$ in human epidermoid KB cells}

We have evaluated the involvement of JNK-1 in the triggering of IFN $\alpha$-induced apoptosis by transfecting KB cells with a plasmid encoding for a wild-type form of JNK-1. Either the treatment of parental cells with IFN $\alpha$ for $24 \mathrm{~h}$ or the overexpression of $\mathrm{JNK}-1^{\mathrm{wt}}$ in transfected cells induced apoptosis in about $30 \%$ of cell population versus $18 \%$ of control cells (Figure 5A and $B$ ). However, the exposure of JNK-1 ${ }^{\text {wt }}$-transfected cells to IFN $\alpha$ for $24 \mathrm{~h}$ caused programmed cell death in almost $65 \%$ of cells (Figure $5 \mathrm{~A}$ and B). The addition of $10 \mathrm{nM} \mathrm{EGF}$ for $12 \mathrm{~h}$ to JNK-1 ${ }^{\mathrm{wt}}$-transfected cells exposed to IFN $\alpha$ for $24 \mathrm{~h}$ was again able to revert this

A
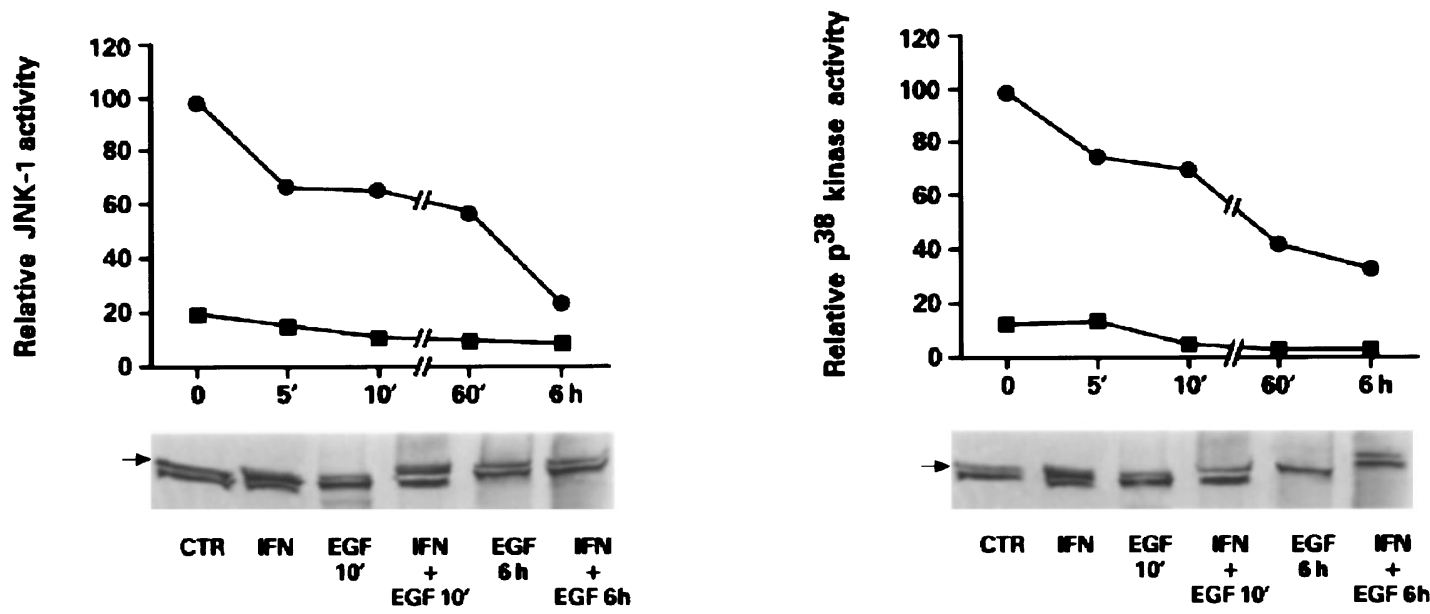

Figure 4 The effects of IFN $\alpha$ and EGF on JNK-1 and MAPK ${ }^{\text {38 }}$ activity. (Upper) Kinase assay performed on the JNK-1 and MAPK ${ }^{\text {p38 }}$ immunoconjugates after different times of exposure to $10 \mathrm{nM} \mathrm{EGF}$ as described in 'Materials and Methods'. Each point represents the mean of at least three different experiments. Standard errors never exceeded 10\% (ם) Untreated KB cells; ( ) IFN $\alpha$-treated KB cells. (Lower) Gel retardation assay on PAGE as described in 'Materials and Methods'. Arrows, bands at higher molecular weight. CTR, untreated; IFN, $48 \mathrm{~h} 1000 \mathrm{IU} / \mathrm{ml}$ IFN $\alpha$; EGF 10', $10^{\prime} 10 \mathrm{nM} \mathrm{EGF}$; IFN+EGF $10^{\prime}, 48 \mathrm{~h} 1000 \mathrm{IU} / \mathrm{ml}$ IFN $\alpha+10^{\prime} 10 \mathrm{nM}$ EGF; EGF $6 \mathrm{~h}, 6 \mathrm{~h} 10 \mathrm{nM}$ EGF; IFN+EGF $6 \mathrm{~h}, 48 \mathrm{~h} 1000 \mathrm{IU} / \mathrm{ml}$ IFN $\alpha+6 \mathrm{~h} 10 \mathrm{nM}$ EGF. The experiments were performed at least three times and always gave similar results 
effect (Figure 5A and B). EGF alone induced apoptosis in almost $30 \%$ of cell population (data not shown) and was also able to reduce the apoptosis determined by the transfection of $\mathrm{JNK}-1^{\mathrm{wt}}$ in KB cells (Figure $5 \mathrm{~A}$ and $\mathrm{B}$ ). Moreover, the JNK-1 ${ }^{\mathrm{wt}}$ transfected cells proliferated at a slower rate than the parental cells in the presence of IFN $\alpha$, thus demonstrating an increase
A

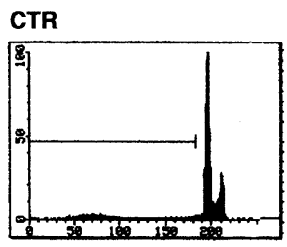

JNK-1WT

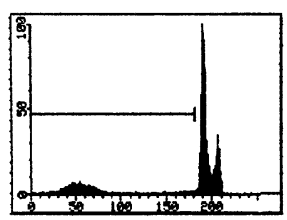

JNK-1 ${ }^{W T}+$ EGF

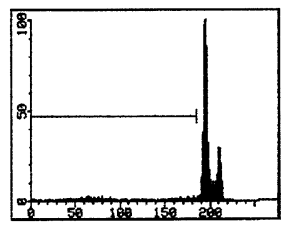

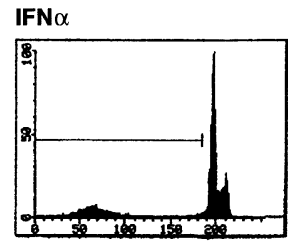

JNK-1WT+ IFN $\alpha$
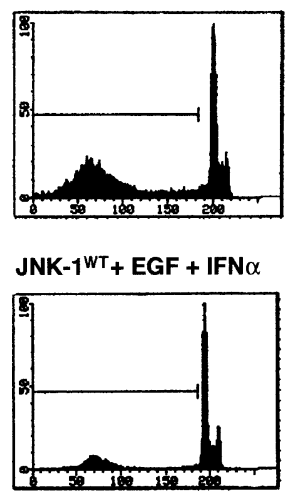

B

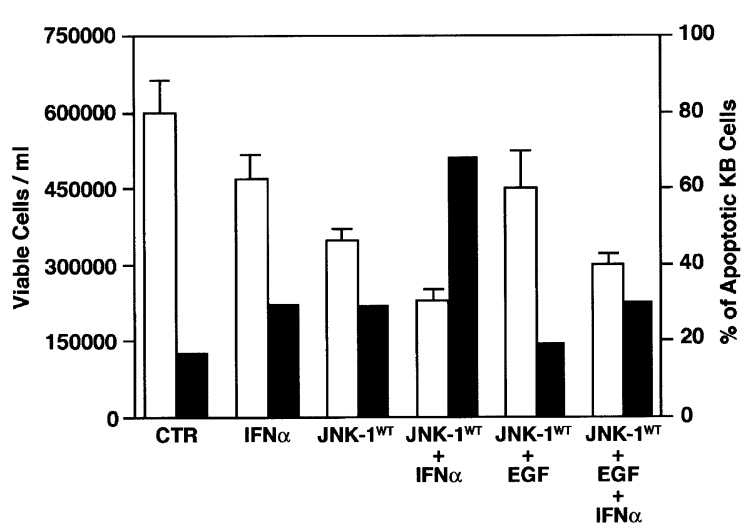

Figure 5 The effects of IFN $\alpha$ and EGF on apoptosis in JNK-1 $1^{\text {wt }}$-transfected $\mathrm{KB}$ cells. (A) FACS analysis of parental or JNK-1 $1^{\mathrm{wt}}$-transfected KB cells exposed to $1000 \mathrm{IU} / \mathrm{ml}$ IFN $\alpha$ for $24 \mathrm{~h}$ and/or $10 \mathrm{nM}$ for $12 \mathrm{~h}$. Cells have been collected, labelled with PI and analyzed as described in 'Materials and Methods'. CTR, Untreated parental cells; IFN $\alpha, 24 \mathrm{~h}$ IFN $\alpha$-treated parental cells; JNK-1 $1^{\text {wt }}$, untreated transfected cells; JNK- $1^{\text {wt }}+$ IFN $\alpha, 24 \mathrm{~h}$ IFN $\alpha$-treated transfected cells; JNK-1 ${ }^{\mathrm{wt}}+\mathrm{EGF}, 12 \mathrm{~h}$ EGF-treated transfected cells; JNK$1^{\mathrm{wt}}+\mathrm{EGF}+\mathrm{IFN} \alpha, 24 \mathrm{~h}$ IFN $\alpha-$ and $12 \mathrm{~h}$ EGF-treated transfected cells. The experiments were performed at least three times and always gave similar results. (B) Apoptosis ( $\mathbf{\square}$ ) was expressed as percentage of cell population and number of viable cells $(\square)$ was determined by haemocytometric cell count after trypan blue dye. CTR, Untreated parental cells; IFN $\alpha, 24 \mathrm{~h}$ IFN $\alpha$-treated parental cells; JNK-1 ${ }^{\text {wt }}$, untreated transfected cells; JNK- $1^{\text {wt }}+$ IFN $\alpha, 24 \mathrm{~h}$ IFN $\alpha$ treated transfected cells; JNK-1 ${ }^{\mathrm{wt}}+\mathrm{EGF}, 12 \mathrm{~h}$ EGF-treated transfected cells; JNK-1 ${ }^{\mathrm{wt}}+\mathrm{EGF}+\mathrm{IFN} \alpha, 24 \mathrm{~h}$ IFN $\alpha-$ and $12 \mathrm{~h}$ EGF-treated transfected cells. For cell proliferation experiments each point represents the mean of at least three different experiments. Bars, S.D. of the anti-proliferative activity of IFN $\alpha$ by stress kinase constitutive activation (Figure 5B). On the other hand, EGF antagonized cell growth inhibition and apoptosis induced by IFN $\alpha$ both in the transfected and parental cells (Figure 5B). Therefore, the overexpression of JNK-1 alone was able to induce apoptosis which was strongly potentiated when transfected cells were exposed to IFN $\alpha$.

\section{Discussion}

We have previously reported that IFN $\alpha$ increases the expression of EGF-R in KB cells; ${ }^{2,4}$ we have also found that receptor upregulation is paralleled by an increased sensitivity of tumour cells to the growth promoting activity of EGF. ${ }^{5}$ We have hypothesized that modulation of receptor expression could be an attempt of tumour cells to escape from growth inhibition induced by IFN $\alpha{ }^{6}$ In this paper we have demonstrated that IFN $\alpha$ induced apoptosis on KB cells, but the upregulation of the EGF-R caused by IFN $\alpha$ appeared to mediate an anti-apoptotic signal. In fact, IFN $\alpha$ and EGF counteracted on apoptosis induction, expression of HSP and modulation of the terminal enzymes of the stress signalling. We have also found that IFN $\alpha$ increased HSPs expression that was, on the other hand, reduced in IFN $\alpha$-treated KB cells by 6-12 h exposure to EGF. Therefore, onset of apoptosis in cells exposed to IFN $\alpha$ was paralleled by HSP increase which was, in turn, neutralized by EGF. These effects can be explained by the finding that HSPs exert an important protective role in the cells against apoptosis induced by several kinds of damaging agents ${ }^{14,15,27,28}$ even if their function is still not completely defined. ${ }^{13,29}$ Moreover, growth factors can inhibit both spontaneous ${ }^{10,12}$ and injury-mediated apoptosis. $^{11}$

We have, moreover, found that the activity of JNK-1 and MAPK $^{\text {p38 }}$ was increased in IFN $\alpha$-treated cells while EGF reduced the activity and the expression of the phosphorylated isoforms of JNK-1 and MAPK ${ }^{\mathrm{p} 38}$ in these cells. Furthermore, the transfection of $\mathrm{KB}$ cells with $\mathrm{JNK}-1^{\mathrm{wt}}$ induced itself apoptosis that was potentiated by IFN $\alpha$ and antagonized by EGF suggesting a direct involvement of JNK-1 in the death mechanisms of IFN $\alpha$ which was an inducer of JNK-1 activity. These effects were paralleled by an increased growth inhibition and therefore by the potentiation of the antiproliferative activity of IFN $\alpha$. On the other hand, EGF antagonized apoptosis induced by IFN $\alpha$ either in JNK-1 ${ }^{\text {wt }}$-transfected or parental cells. The latter effect suggests that the protection from apoptosis induced by EGF likely targets JNK-1 as a signalling molecule. The counteracting effect of EGF on the apoptosis and stress protein expression was, therefore, paralleled by an antagonistic activity on the target enzymes of a stress signal pathway ${ }^{24,30}$ which is involved in the regulation of gene expression. ${ }^{31}$ In fact, the activation of these MAPK isoenzymes have been correlated with the triggering of apoptosis induced by cytokines, such as TGF $\beta$, in several cell models. ${ }^{18,19}$ Moreover, it has been demonstrated that the onset of apoptosis by fas or cisplatin is correlated with a sustained JNK activation. ${ }^{25,32}$ Interestingly, we have found an increase of the activity of these enzymes after a chronic exposure of KB cells to IFN $\alpha$ suggesting, therefore, 
the occurrence of events similar to those previously reported by others. ${ }^{25}$ Evidence is raising on the involvement of SAPK/JNK in the onset of programmed cell death independently from bcl-2 expression and caspase inhibition $^{26}$ suggesting a key role of these enzymes in apoptosis through the regulation of still not identified mediators. However, further investigations are required in order to clarify the role of caspases in our experimental model. A cross-talk between SAPK and HSPs exists since MAPK ${ }^{\text {p38 }}$ can activate the MAPK-activated protein kinase 2 that, in turn, phosphorylates HSP $-27^{33}$ that is modulated by EGF and IFN $\alpha$ in our experimental system. Our results suggest that IFN $\alpha$ induced apoptosis through the chronic stimulation of stress-activated MAPK isoenzymes while the increased expression of HSP represented an attempt of tumour cells to escape from death induced by the cytokine.

Notably, exposure of KB cells to EGF alone for $12 \mathrm{~h}$ induced apoptosis that was paralleled by an increase of PCNA expression, a marker of proliferating cells. ${ }^{4}$ Apoptosis is caused by exposure to EGF also in human breast cancer cells. ${ }^{34}$ The induction of apoptosis by EGF in $\mathrm{KB}$ cells could be interpreted in the light of the dual signal model which postulates that proliferation and apoptosis are coupled functions of dominant oncogenes such as c-myc and c-fos and, therefore, not always a consequence of the conflict between growth suppressive and promoting stimuli. $^{35-39}$ This hypothesis is supported by the observation that the chimeric homeobox fusion gene E2A-PBX1 causes lymphomas in transgenic mice where massive lymphocyte apoptosis is detected in the pre-malignant phase. ${ }^{40}$ Therefore, it is not surprising that a part of active proliferating KB cells exposed to EGF underwent apoptosis. In our experimental model EGF induced apoptosis when it maximally stimulated cell growth. On the other hand, the growth factor acted as a survival factor when the cells were growth inhibited by IFN $\alpha$.

In conclusion, we have demonstrated that EGF-R upregulation induced by IFN $\alpha$ paralleled the induction of apoptosis and the enhanced expression of stress proteins in human epidermoid cancer KB cells. Apoptosis induction was mediated by a stress signalling which targeted JNK-1. The terminal enzymes of this pathway represented, therefore, the effectors of apoptosis. All these events were antagonized by EGF, that acted as a survival factor and whose effects occurred through down-regulation of stress kinase activity. Our experimental findings could be useful in the design of new anti-cancer strategies based on the overexpression of JNK-1/MAPK ${ }^{\mathrm{p} 38}$ by viral vector transduction or on their activation by pharmacological agents in combination with IFN $\alpha$.

\section{Materials and Methods}

\section{Materials}

Dulbecco's modified Eagle's medium (DMEM), bovine serum albumin (BSA) and foetal bovine serum (FBS) were purchased from Flow Laboratories (Milan, Italy). Tissue culture plasticware was from Becton Dickinson (Lincoln Park, NJ, USA). IFN $\alpha$ was a gift of Schering (Schering-Plough, NJ, USA). Protein Sepharose was purchased from
Sigma (St. Louis, MO, USA). Anti-HSP-70 C92F3A-5 and anti-HSP-90 AC88 monoclonal antibodies (Mab) were from Stress Gen Biotech. Co. (Victoria, BC, Canada) and anti-HSP-27 G3.1 MAb from Affinity Bioreagents (Neshanic Station, NJ, USA). Anti-JNK-1 C-17 and antiMAPK $^{\text {p38 }}$ C-20 rabbit antisera were from Santa Cruz Biotechnology (Santa Cruz, CA, USA). The pCDNA3-Flag-JNK-1 ${ }^{\text {wt }}$ plasmid was kindly donated by Dr. R.J. Davis (Howard Hughes Medical Institute and Program in Molecular Medicine, Department of Biochemistry and Molecular Biology, University of Massachusetts Medical School, Worcester, MA, USA).

\section{Cell culture}

The human oropharyngeal epidermoid carcinoma KB cell line, obtained from the American Tissue Type Culture Collection (Rockville, MD, USA) was grown in DMEM supplemented with heat inactivated 10\% FBS, $20 \mathrm{mM} \mathrm{N}$-2-hydroxyethylpiperazine- $\mathrm{N}-2$ 'ethanesulphonic acid (HEPES), $100 \mathrm{U} / \mathrm{ml}$ penicillin, $100 \mu \mathrm{g} / \mathrm{ml}$ streptomycin, $1 \%$ L-glutamine and $1 \%$ sodium pyruvate. The cells were grown in a humidified atmosphere of $95 \%$ air $/ 5 \% \quad \mathrm{CO}_{2}$ at $37^{\circ} \mathrm{C}$. For apoptosis evaluation the cells were treated with $48 \mathrm{~h}$ $1000 \mathrm{IU} / \mathrm{ml} \mathrm{IFN} \alpha$ and/or $12 \mathrm{~h} 10 \mathrm{nM}$ EGF. When EGF was added to IFN $\alpha$-treated KB cells, the cytokine was not withheld from the medium.

\section{Western blot analysis}

$\mathrm{KB}$ cells were grown for $48 \mathrm{~h}$ with or without $1000 \mathrm{IU} / \mathrm{ml} \mathrm{IFN} \alpha$ and were thereafter exposed for the indicated times to $10 \mathrm{nM} \mathrm{EGF}$ at $37^{\circ} \mathrm{C}$ as described above. For cell extract preparation, the cells were washed twice with ice-cold phosphate buffered saline (PBS)/BSA, scraped, and centrifuged for $30 \mathrm{~min}$ at $4^{\circ} \mathrm{C}$ in $1 \mathrm{ml}$ of lysis buffer ( $1 \%$ Triton, $0.5 \%$ sodium deoxycholate, $0.1 \mathrm{M} \mathrm{NaCl}, 1 \mathrm{mM}$ ethylenediaminetetracetic acid (EDTA), pH 7.5, $10 \mathrm{mM} \mathrm{Na} \mathrm{HPO}_{4}, \mathrm{pH} \mathrm{7.4,} 10 \mathrm{mM}$ phenylmethylsulphonyl fluoride (PMSF), $25 \mathrm{mM}$ benzamidin, $1 \mathrm{mM}$ leupeptin, 0.025 units $/ \mathrm{ml}$ aprotinin). Equal amounts of cell proteins were separated by sodium-dodecyl-sulphate (SDS)-polyacrylamide gel electrophoresis (PAGE). The proteins on the gels were electrotransferred to nitrocellulose and reacted with the different MAbs or rabbit antisera. Specific antibody binding has been detected by colorimetric reaction following alkaline phosphatase-linked anti-mouse or anti-rabbit antibody blotting.

\section{Gel retardation assay}

KB cells were grown and lysed as described above. Then the cells were rapidly washed with ice-cold PBS without $\mathrm{Ca}^{2+}$ and $\mathrm{Mg}^{2+}$. A hot SDS total cell extract was prepared by immediately scraping the cells into boiling SDS-PAGE sample buffer and drawing through a 23gauge needle ten times to shear DNA. Then Western blot analysis was performed as described above.

\section{Internucleosomal DNA fragmentation (Ladder)}

DNA fragmentation was measured after extraction of low molecular weight DNA. Briefly, $10 \times 10^{6}$ cells were resuspended in $900 \mu \mathrm{l}$ $1 \times$ Tris-EDTA buffer and lysed with $25 \mu \mathrm{l} 20 \%$ SDS. DNA was precipitated in ethanol for $6 \mathrm{~h}$ in the presence of $5 \mathrm{M} \mathrm{NaCl}$. The high molecular weight fraction was sedimented by high speed centrifugation, and the fragmented DNA was extracted from the aqueous phase with phenol and chloroform and then precipitated with ethanol. After resuspension in water, DNA was electrophoresed using 1.5\% agarose 
gel and visualized by ultraviolet light following ethidium bromide staining.

\section{TUNEL}

For TUNEL assay, after washing in PBS supplemented in $0.1 \%$ BSA, cells were treated with in situ detection kit, according to manufacturers (Boehringer Mannheim Biochemicals). Nuclei with fragmented DNA were visualized by Fast Red staining. Slides were mounted with Moviol 4-88 (Calbiochem) and examined with a Zeiss microscope.

\section{Lipofection}

$3.5 \times 10^{5} \mathrm{~KB}$ cells were seeded in $35-\mathrm{mm}$ dishes and after overnight incubation at $37^{\circ} \mathrm{C}$ were washed once with serum and antibiotics free medium and exposed to a lipofectamine/JNK-1 ${ }^{\text {wt }}$ plasmid $(1 \mu \mathrm{g} / \mathrm{dish})$ mixture. The cells were incubated for $3 \mathrm{~h}$ at $37^{\circ} \mathrm{C}$ and then the mixture was withdrawn and complete medium was added. Then, the cells were exposed to $1000 \mathrm{IU} / \mathrm{ml} \mathrm{IFN} \alpha$ for $24 \mathrm{~h}$ and/or $10 \mathrm{nM} \mathrm{EGF}$ for $12 \mathrm{~h}$. After incubation at $37^{\circ} \mathrm{C}$ the cells were processed for FACS analysis as described below.

\section{Evaluation of apoptosis by DNA-flow cytometry}

Cells were centrifuged and directly stained in a propidium iodide $(\mathrm{PI})$ solution (50 mg PI in $0.1 \%$ sodium citrate, $0.1 \% \mathrm{NP} 40, \mathrm{pH} 7.4$ ) overnight at $4^{\circ} \mathrm{C}$ in the dark. Flow cytometric analysis was performed using a FACSCAN flow cytometer (Becton Dickinson, San Jose, CA, USA) interfaced with a Hewlett Packard computer (mod.310) for data analysis. To evaluate cell apoptosis, PI fluorescence was collected as FL2 (Log scale) by the CellFIT software (Becton Dickinson). The data were acquired after analysis of at least 20000 events.

\section{Kinase activity assay}

KB cells were cultured and treated as described above. Then KB cells were washed twice with ice-cold PBS, scraped and lysed for $1 \mathrm{~h}$ at $4^{\circ} \mathrm{C}$ in the following buffer: $10 \mathrm{mM}$ TRIS, $150 \mathrm{mM} \mathrm{NaCl}, 2 \mathrm{mM}$ Ethyleneglycol-bis ( $\beta$-aminoethyl Ether) $\mathrm{N}, \mathrm{N}, \mathrm{N}^{\prime}, \mathrm{N}^{\prime}$-tetraacetic acid (EGTA), $2 \mathrm{mM}$ dithiothreitol (DTT), $1 \mathrm{mM}$ sodium orthovanadate, $1 \mathrm{mM}$ PMSF, $10 \mu \mathrm{g} / \mathrm{ml}$ aprotinin, $10 \mu \mathrm{g} / \mathrm{ml}$ leupeptin and $1 \%$ glycerol. Equalized amounts of proteins from lysates of KB cells $(50 \mu \mathrm{l})$ were incubated for $90 \mathrm{~min}$ at $4^{\circ} \mathrm{C}$ with $50 \mu \mathrm{l}$ of protein A-Sepharose conjugated to $25 \mu \mathrm{g}$ anti-JNK-1 or anti-MAPK ${ }^{\mathrm{p} 38}$ rabbit antisera. The suspension was centrifuged at $14000 \times g$, the supernatant discarded, and the immunoprecipitated washed twice with $250 \mu$ of the following buffer: $20 \mathrm{mM}$ Tris-acetate, $\mathrm{pH} 7.0\left(20^{\circ} \mathrm{C}\right), 0.27 \mathrm{M}$ Sucrose, $1 \mathrm{mM}$ EDTA, $1 \mathrm{mM}$ EGTA, $1 \mathrm{mM}$ sodium orthovanadate, $10 \mathrm{mM}$ sodium glycerophosphate, $50 \mathrm{mM}$ sodium fluoride, $5 \mathrm{mM}$ sodium pyrophosphate, $1 \%$ Triton X-100, 0.1\% 2-mercaptoethanol, $1 \mathrm{mM}$ benzamidine, $0.2 \mathrm{mM}$ PMSF and $0.5 \mathrm{M} \mathrm{NaCl}$. The immunoprecipitated were washed once with $250 \mu \mathrm{l}$ of the following buffer: $50 \mathrm{mM}$ Tris- $\mathrm{HCl}, \mathrm{pH}$ $7.5\left(20^{\circ} \mathrm{C}\right), 0.03 \%$ Brij-35, $0.1 \mathrm{mM}$ EGTA and 0.1\% 2-mercaptoethanol. Then immunoprecipitated were incubated for $30 \mathrm{~min}$ at $30^{\circ} \mathrm{C}$ with $5 \mu$ of a solution containing $1.2 \mathrm{mM} \mathrm{Mg}^{2+}$ adenosine $5^{\prime}$-triphosphate (ATP) with $200 \mu \mathrm{Ci} / \mathrm{ml}$ of ATP $\gamma^{32} \mathrm{P}$ and $15 \mu \mathrm{g}$ of GST-C-JUN (amino acid residues 1-79), for JNK-1 activity, and GST-ATF2 (1-109), for MAPK $^{\text {p38 }}$ activity. The reaction was stopped with the addition of $2.94 \%$ $(\mathrm{w} / \mathrm{v})$ ortophosphoric acid and red carmosin solution and then microfuged for $15 \mathrm{~s}$. The reaction mixtures were spotted onto phosphocellulose filters (Whatman P81) and washed three times in $1 \%$ acetic acid. Filters were air-dried and then counted by liquid scintillation using Omnifluor/toluene (DuPont-New England Nuclear, Boston, MA, USA).

\section{Acknowledgements}

These studies have been supported by the Italian Association for Cancer Research (AIRC). We thank for his active cooperation Dr. R.J. Davis, Howard Hughes Medical Institute and Program in Molecular Medicine, Department of Biochemistry and Molecular Biology, University of Massachusetts Medical School, 373 Plantation Street, Worcester, MA 01605, USA.

\section{References}

1. Cohen MC and Cohen S (1996) Cytokine function: a study in biologic diversity. Am. J. Clin. Pathol. 105: 589-598

2. Budillon A, Tagliaferri $P$, Caraglia M, Torrisi MR, Normanno N, lacobelli S, Palmieri G, Stoppelli MP, Frati L and Bianco AR(1991) Upregulation of epidermal growth factor receptor induced by alpha-interferon in human epidermoid cancer cells. Cancer Res. 51: 1294-1299

3. Caraglia M, Libroia AM, Corradino S, Coppola V, Guarrasi R, Barile C, Genua G, Bianco AR and Tagliaferri $\mathrm{P}(1994) \alpha$-Interferon induces depletion of intracellular iron content and upregulation of functional transferrin receptors on human epidermoid cancer KB cells. Biochem. Biophys. Res. Commun. 203: 281-288

4. Caraglia M, Passeggio A, Beninati S, Leardi A, Nicolini L, Improta S, Pinto A, Bianco AR, Tagliaferri P and Abbruzzese A (1997) Interferon $\alpha 2$ recombinant and epidermal growth factor modulate proliferation and hypusine synthesis in human epidermoid cancer KB cells. Biochem. J. 324: 737-741

5. Caraglia M, Leardi A, Corradino S, Ciardiello F, Budillon A, Guarrasi R, Bianco AR and Tagliaferri $P(1995) \alpha$-Interferon potentiates epidermal growth factor receptor-mediated effects on human epidermoid carcinoma KB cells. Int. J. Cancer 61: $342-347$

6. Tagliaferri P, Caraglia M, Muraro R, Budillon A, Pinto A and Bianco AR (1994) Pharmacological modulation of peptide growth factor receptor expression on tumor cells as a basis for cancer therapy. Anti-Cancer Drugs 5: 379-393

7. Rodriguez-Villanueva $J$ and McDonnell TJ (1995) Induction of apoptotic cell death in non-melanoma skin cancer by interferon- $\alpha$. Int. J. Cancer 61: 110-114

8. Roth W, Wagenknecht B, Dichgans J and Weller MJ (1998) Interferon-alpha enhances CD95L-induced apoptosis of human malignant glioma cells. J. Neuroimmunol. 87: 121-129

9. Tanaka N, Sato M, Lamphier MS, Nozawa H, Oda E, Noguchi S, Schreiber RD, Tsujimoto Y and Taniguchi T (1998) Type I interferons are essential mediators of apoptotic death in virally infected cells. Genes Cells 3: 29-37

10. Tilly JL, Billig H, Kowalski KI and Hsueh AJ (1992) Epidermal growth factor and basic fibroblast growth factor suppress the spontaneous onset of apoptosis in cultured rat ovarian granulosa cells and follicles by a tyrosine kinase-dependent mechanism. Mol. Endocrinol. 6: 1942-1950.

11. Peng H, Wen TC, Tanaka J, Maeda N, Matsuda S, Desaki J, Sudo S, Zhang Band Sakanaka M (1998) Epidermal growth factor protects neuronal cells in vivo and in vitro against transient forebrain ischemia- and free radical-induced injuries. J. Cereb. Blood Flow Metab. 18: 349-360

12. Stoll SW, Benedict M, Mitra R, Hiniker A, Elder JT and Nunez G (1998) EGF receptor signaling inhibits keratinocyte apoptosis: evidence for mediation by Bcl-XL. Oncogene 16: 1493-1499

13. Welsh MJ and Gaestel M (1998) Small heat-shock protein family: function in health and disease. Ann. N.Y. Acad. Sci. 851: 28-35

14. Mestril R, Chi SH, Sayen MR, O'Reilly K and Dillmann WH (1994) Expression of inducible stress protein 70 in rat heart myogenic cells confers protection against simulated ischemia-induced injury. J. Clin. Invest. 93: 759-767

15. Xu Q, Hu Y, Kleindienst R and Wick G (1997) Nitric oxide induces heat-shock protein 70 expression in vascular smooth muscle cells via activation of heat shock factor 1. J. Clin. Invest. 100: 1089-1097

16. Laderoute KR, Grant TD, Murphy BJ and Sutherland RM (1992) Enhanced epidermal growth factor receptor synthesis in human squamous carcinoma cells exposed to low levels of oxygen. Int. J. Cancer 52: 428-432 
17. Ichijo $H$, Nishida E, Irie $K$, ten Dijke $P$, Saitoh $M$, Moriguchi $T$, Takagi $M$, Matsumoto K, Miyazono Kand Gotoh Y (1997) Induction of apoptosis by ASK1, a mammalian MAPKKK that activates SAPK/JNK and p38 signaling pathways. Science 275: 90-94

18. Wang W, Zhou G, Hu MCT, Yao Z and Tan TH (1997) Activation of the hematopoietic progenitor kinase-1 (HPK1)-dependent, stress-activated c-Jun $\mathrm{N}$-terminal kinase (JNK) pathway by transforming growth factor beta (TGF-beta)activated kinase (TAK1), a kinase mediator of TGF beta signal transduction. J. Biol. Chem. 272: 22771-22775

19. Frey RS and Mulder KM (1997) Involvement of extracellular signal-regulated kinase 2 and stress-activated protein kinase/Jun $\mathrm{N}$-terminal kinase activation by transforming growth factor beta in the negative growth control of breast cancer cells. Cancer Res. 57: 628-633

20. Xia Z, Dickens M, Raingeaud J, Davis RJ and Greenberg ME (1995) Opposing effects of ERK and JNK-p38 MAP kinases on apoptosis. Science 270: 13261331

21. Yan CYI and Greene LA (1998) Prevention of PC12 cell death by $\mathrm{N}$ acetylcysteine requires activation of the Ras pathway. J. Neurosci. 18: 40424049

22. Aikawa R, Komuro I, Yamazaki T, Zou Y, Kudoh S, Tanaka M, Shiojima I, Hiroi Y and Yazaki Y (1997) Oxidative stress activates extracellular signal-regulated kinases through Src and Ras in cultured cardiac myocytes of neonatal rats. J. Clin. Invest. 100: 1813-1821

23. Stadheim TA and Kucera GL (1998) Extracellular signal-regulated kinase (ERK) activity is required for TPA-mediated inhibition of drug-induced apoptosis. Biochem. Biophys. Res. Commun. 245: 266-271

24. Derijard B, Raingeaud J, Barrett T, Wu I-H, Han J, Ulevitch RJ and Davis RJ (1995) Independent human MAP kinase signal transduction pathways defined by MEK and MKK isoforms. Science 267: 682-685

25. Goillot E, Raingeaud J, Ranger A, Tepper RI, Davis RJ, Harlow E and Sanchez I (1997) Mitogen-activated protein kinase-mediated Fas apoptotic signaling pathway. Proc. Natl. Acad. Sci. USA 94: 3302-3307

26. Zanke BW, Lee C, Arab S and Tannock IF (1998) Death of tumor cells after intracellular acidification is dependent on stress-activated protein kinases (SAPK/JNK) pathway activation and cannot be inhibited by Bcl-2 expression or interleukin 1beta-converting enzyme inhibition. Cancer Res. 58: 2801-2808
27. Mosser DD and Martin LH (1992) Induced thermotolerance to apoptosis in a human T lymphocyte cell line. J. Cell Physiol. 151: 561-570

28. Wei $Y Q$, Zhao X, Kariya $Y$, Fukata H, Teshigawara K and Uchida A (1994) Induction of apoptosis by quercetin: involvement of heat shock protein. Cancer Res. 54: 4952-4957

29. Burel C, Mezger V, Pinto M, Rallu M, Trigon S and Morange M (1992) Mammalian heat shock protein families. Expression and functions. Experientia 48: 629-633

30. Karin M (1998) Mitogen-activated protein kinase cascades as regulators of stress responses. Ann. N.Y. Acad. Sci. 851: 139-146

31. Treisman R (1996) Regulation of transcription by MAP kinase cascades. Curr. Opin. Cell. Biol. 8: 205-215

32. Sanchez-Perez I, Murguia JR and Perona R (1998) Cisplatin induces a persistent activation of JNK that is related to cell death. Oncogene 16: 533-540

33. Ahlers A, Engel K, Sott C, Gaestel M, Herrmann F and Brach MA (1994) Interleukin-3 and granulocyte-macrophage colony-stimulating factor induce activation of the MAPKAP kinase 2 resulting in in vitro serine phosphorylation of the small heat shock protein (Hsp27). Blood 83: 1791-1798

34. Armstrong D, Kaufmann SH, Ottaviano YL, Furuya Y, Buckley JA, Isaacs JT and Davidson NE (1994) Epidermal growth factor-mediated apoptosis of MDA-MB468 human breast cancer cells. Cancer Res. 54: 5280-5283

35. Bokoch GM (1998) Caspase-mediated activation of PAK2 during apoptosis: proteolytic kinase activation as a general mechanism of apoptotic signal transduction? Cell Death Differ. 5: 637-645

36. Harrington EA, Fanidi A and Evan GI (1994) Oncogenes and cell death. Curr. Opin. Gen. Dev. 4: 120-129

37. Evan GI, Wyllie AH, Gilbert CS, Littlewood TD, Land H, Brooks M, Waters CM, Penn LZ and Hancock DC (1992) Induction of apoptosis in fibroblast by c-myc protein. Cell 69: $119-128$

38. Smeyne R, Vendrell M, Hayward M, Baker S, Miao G, Schilling K, Robertson L, Curran T and Morgan J (1993) Continuous C-fos expression precedes programmed cell-death in vivo. Nature (London) 363: 166 - 169

39. Krontiris TG (1995) Oncogenes. New Engl. J. Med. 333: 303-306

40. Dedera DA, Walker EK, LeBrun DP, Sen-Majumdar A, Stevens ME, Barsh GS and Cleary ML (1993) Chimeric homeobox gene E2A-PBX1 induces proliferation, apoptosis, and malignant lymphomas in transgenic mice. Cell 74: $833-843$ 